\title{
In support of Long Distance Agree*
}

\author{
Artemis Alexiadou, Elena Anagnostopoulou ${ }^{\mathrm{ii}}$, Gianina Iordachioaia ${ }^{\mathrm{i}}$ \& Mihaela Marchis ${ }^{\mathrm{i}}$ \\ Universität Stuttgart ${ }^{\mathrm{i}}$, University of Crete ${ }^{\mathrm{ii}}$ \\ artemis/gianina/mihaela@ifla.uni-stuttgart.de, elena@phl.uoc.gr
}

\section{Overview}

In the recent literature the phenomenon of long distance agreement has become the focus of several studies as it seems to violate certain locality conditions which require that agreeing elements in general stand in clause-mate relationships. In particular, it involves a verb agreeing with a constituent which is located in the verb's clausal complement and hence poses a challenge for theories that assume a strictly local relationship for agreement.

In this paper we present empirical evidence from Greek and Romanian for the reality of long distance agreement. Specifically, we focus on raising constructions in these two languages and we show that they do not involve movement but rather instantiate long distance agreement. We further argue that subjunctives allowing long distance agreement lack both a CP layer and semantic Tense. However, since the embedded verb also bears phi-features, these constructions pose a further problem for assumptions that view the presence of phifeatures as evidence for the presence of a $\mathrm{C}$ layer. Finally, we raise the question of the common properties that these languages have that lead to the presence of long distance agreement.

\section{2. (Backward) Raising and Long Distance Agreement}

In a recent paper, Polinsky \& Potsdam (P\&P) (2007) point out that under the Copy and Delete theory of movement, a raising construction such as (1) should be analysed as involving copying of the moved constituent with sub-sequent deletion of one of the two copies. In general, either the higher or the lower copy can be deleted or both could be pronounced (2). This leads to the typology in (3). [тP Bill [vе (Bill) seem [IP Bill to [ ${ }_{\mathrm{vP}}$ Bill cut the line]]]] Subject Raising
a. [higher copy
lower copy]
anaphora
b. [higher copy
lower copy]
cataphora
c. [higher copy
lower copy]
resumption

(3) Typology of Raising in Polinsky \& Potsdam 2007 (P\&P): ${ }^{1}$

\footnotetext{
* An earlier version of this paper was presented at the GGS meeting in May 2008 in Berlin. We would like to thank Alex Grosu, Masha Polinsky, Eric Potsdam and Winfried Lechner for comments and suggestions. Special thanks to Gereon Müller for helpful discussions of this paper.

1 P\&P point out that the same patterns can be found in the case of Control structures, under the analysis of Control as Movement (see Hornstein 1999 and subsequent work). We further refer the reader to Alboiu (2007), Alexiadou et al. (to appear), where it is argued that Greek and Romanian have extensive backward control across Obligatory Control (OC) complements.
} 


\begin{tabular}{|c|c|c|}
\hline Higher copy pronounced & Lower copy pronounced & Structure \\
\hline$\sqrt{*} *$ & Forward Raising \\
\hline \multirow{2}{*}{$*$} & $\sqrt{ }$ & Backward Raising \\
\hline$\sqrt{\mid} \sqrt{ }$ & Resumption \\
\hline
\end{tabular}

P\&P (2007, 2008) furthermore argue that backward raising does not always involve actual subject-to-subject raising, i.e. movement followed by deletion of the higher copy, as in ( $2 \mathrm{~b})$. Adyghe, a Caucasian language spoken in the south of Russia and Turkey has real backward raising. On the other hand, Greek, which has been analysed by Alexiadou \& Anagnostopoulou (A\&A 1999/2002) as having overt or covert raising out of subjunctive complements, actually has Long Distance Agreement (LDA) which requires Agree (Chomsky 2000, 2001).

Our contribution to this discussion is as follows. First, we revisit Greek in the light of P\&P's findings and conclude that the instances analysed by A\&A (1999/2002) as covert raising indeed involve LDA rather than actual movement. Second, we present evidence that Romanian also has LDA across subjunctive complements, similarly to Greek. And third, we propose an analysis for LDA focusing on the conditions under which LDA patterns obtain in the languages under discussion.

\section{P\&P's criteria for Backward Raising}

Evidence for Backward Raising (BR) seems scant. ${ }^{2}$ P\&P $(2007,2008)$ discuss Adyghe as a language with real BR. Adyghe is a Northwest Caucasian language with ergative case marking and relative free word order. Raising verbs in this language are 'become, turn to', 'happen to', 'be likely to' and the aspectual verbs 'begin' and 'stop'. Constructions involving such verbs are biclausal, as e.g. shown by the fact that the event in each clause can be modified independently, as in (4) (P\&P's 2008 ex. (9); further arguments include the possibility of two negations and NPI licensing in both clauses):

\begin{tabular}{|c|c|c|c|}
\hline \multirow[t]{2}{*}{ a. } & 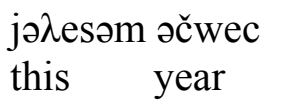 & $\begin{array}{l}{\left[{ }^{\left[s h_{w}\right.} \text { enč'əm-če }\right.} \\
\text { gun-INSTR }\end{array}$ & $\begin{array}{ll}\text { twe } & \text { sə-we-new] } \\
\text { twice } & 1 \text { SG-shoot-SUP }\end{array}$ \\
\hline & $\begin{array}{l}\chi_{\mathrm{w}} \mathrm{Ke} \\
\text { turned out } \\
\text { 'This year I turne }\end{array}$ & t to shoot my gu & ce (in a row)' \\
\hline b. & 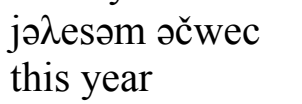 & $\begin{array}{l}{\left[{ }^{\text {šh }}{ }_{\mathrm{w}} \text { enč'วm-če }\right.} \\
\text { gun-INSTR }\end{array}$ & $\begin{array}{l}\text { sə-we-new] } \\
\text { 1SG-shoot-SUP }\end{array}$ \\
\hline & $\begin{array}{ll}\text { twe } & \chi_{\mathrm{w}} \mathrm{Ke} \\
\text { twice } & \text { turned out }\end{array}$ & & \\
\hline
\end{tabular}

Initial evidence for Raising in Adyghe is provided by the preservation of idiomatic meaning in $(5 \mathrm{c})$ which shows that the matrix predicate has a non-thematic subject:
a. $\quad$ axe-me posme-r
a-txə-new]
feža- R-ex
3-pl ERG letter-ABS 3-pl-ERG-write-SUP begin-past-pl
'They began to write a letter.'

\footnotetext{
${ }^{2}$ Evidence from more languages is given for Backward Control (BC). B(subject)C can be observed in several Nahk-Dagestanian languages, in Northwest Caucasian, in Malagasy, and in Korean. According to P\&P (2007), Tsez offers the most compelling case of obligatory subject control. In Alexiadou et al. (to appear), we argue that Greek and Romanian present a stronger argument for BC.
} 

b. ə-pe hozə-r qәrexə
3-sg.poss nose smoke-ABS blows
'S/he is furious.' (lit. smoke is coming out of his/her nose)
c. [ə-pe hozə-r qərexjə-new] qəčəč əR
3-sg.poss nose smok-ABS blow-SUP happened
'S/he happened to be furious.'

In contexts like (5c) the subject is in the lower clause as its case is determined by the lower predicate (ERG if transitive, ABS if intransitive). But there must also be a silent copy in the main subject position, as the subject is able to bind a reflexive in the matrix clause:

$$
\begin{array}{ll}
\text { [axe-me pəsme-r a-txə-new] } & \text { ze-feža- R-ex } \\
\text { 3-pl ERG letterABS 3-pl-ERG-write-SUP } & \text { REFL.begin-past-pl } \\
\text { 'They began to write a letter for themselves.' }
\end{array}
$$

Moreover, a quantified DP subject in the lower clause can have wide scope with respect to the negation in the higher clause (see P\&P 2007, 2008 for examples).

P\&P's conclusion is that Adyghe has BR. They propose an analysis as in (7), where the higher copy is deleted.

$$
\begin{array}{llll}
\text { axe-r } \quad \text { axe-me pəsme-r a-txə-new] } & \text { feža- R-ex } & \text { BR } \\
\text { 3-pl-ABS } & \text { 3pl-ERG letter-ABS 3pl-ERG-write-SUP } & \text { begin-past-pl } & \\
\text { 'They began to write a letter.' } &
\end{array}
$$

P\&P distinguish between fake BR and real BR and suggest that Greek is a language with fake $\mathrm{BR}$, in spite of the evidence from the agreement patterns (the higher verb obligatorily agrees with the lower subject, even when the subject is thematically dependent on the lower verb as in the case of idioms; see Alexiadou \& Anagnostopoulou 1999 and below for discussion); Greek examples as in (8) are analysed as an instance of long distance agreement (LDA):

a. stamatisan na diavazun ta pedia vivlia tu Kazandzaki stopped-3pl subj read-3pl the children books Kazandzakis 'The children stopped reading books by Kazandzakis.'
Agree
b. [TP stamatisan [TP na diavazun [DP ta pedia]]] stopped subj read.3PL the children

LDA

In the following sections, we systematically go over the arguments in support of this conclusion, while at the same time adding Romanian to the discussion.

\section{Control and Raising constructions in Greek and Romanian}

\subsection{Control subjunctives}


In both Greek and Romanian, Control is instantiated in a sub-set of subjunctive complement clauses, as these languages generally lack infinitives. ${ }^{3}$ The debate so far has concentrated on whether the null subject of the subjunctive clause should be pro or PRO or more recently an A-trace, (Iatridou 1988/1993, Varlokosta 1994, Terzi 1992, Tsoulas 1993, Philippaki \& Katsimali 1999, Spyropoulos 2007 Kapetagianni \& Seely 2007, Roussou to appear among others for Greek; Dobrovie-Sorin 1994, 2000, Motapanyane 1995, Terzi 1992, Alboiu 2007 among others for Romanian). ${ }^{4}$

In Greek, subjunctive complement clauses are introduced by the subjunctive marker $n a(9) .{ }^{5}$ In Romanian, the subjective marker is să (10). In both languages, the embedded verb, similarly to the matrix verb, shows agreement in number and person with the matrix subject.

$$
\begin{aligned}
& \text { O Petros/ego kser-i/-o na koliba-i/-o } \\
& \text { Peter-nom/I knows/know-1sg subj swim-3sg/-1sg } \\
& \text { 'Peter knows how to swim/I know how to swim.' }
\end{aligned}
$$

Greek

Ion a uitat să limpezească cămaşa.

Romanian

Ion forgot-3sg subj rinse-3sg shirt-the

'Ion forgot to rinse the shirt.'

In addition, Romanian has a second type of subjunctive complements, introduced by $c a$ (the subjunctive complementizer) plus the subjunctive marker $s a \check{\text { : }}$

$$
\begin{aligned}
& \text { Ion vrea ca azi să cânte la violoncel } \\
& \text { Ion wants that today subj play at cello }
\end{aligned}
$$

$c a$ is absent in both Obligatory Control and raising complements (cf. Grosu \& Horvath 1987).

Greek subjunctives and Romanian să (but not $c a$ să) subjunctives lack obviation effects. In this respect, they behave like infinitives (see Terzi 1992 for a detailed discussion).
a. $\quad \mathrm{Juan}_{\mathrm{i}}$ quiere que $\mathrm{EC}_{\mathrm{j} / *_{\mathrm{i}} \text { venga }}$
John wants that comes-subj
Spanish

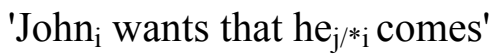
b. o Janis $\mathrm{s}_{\mathrm{i}}$ theli na $\mathrm{EC}_{\mathrm{i} / \mathrm{j}}$ erthi
John-nom wants subj come-3sg
'John wants that he $\mathrm{i}_{\mathrm{i} / \mathrm{j}}$ comes'

\footnotetext{
${ }^{3}$ As is well known, Greek has lost infinitives entirely. Romanian does actually have infinitives, which may appear in Raising structures but not in Control environments:

(i) a. Maria pare a citi (??Maria) o carte (Maria).

Mary seems to read a book

b. * Maria încearcă a citi o carte.

Mary tries to read a book.

4 For Greek, it has been shown that in principle nominative features are available in the complement clause, see e.g. (Philippaki \& Katsimali 1999, Spyropoulos 2007); (but see Alboiu 2007 for a different view with respect to Romanian). The argument is based on the availability of NP-modifiers/intensifiers licensed in the lower clause by the higher subject and this has been seen as evidence that the lower subject is pro. Landau (2004, 2007) argues that if PRO can be assigned case, these examples are straightforwardly accounted for.
(i) kolimbai (o Janis)
monos tu
swim-3sg (John)
alone-nom

$\begin{array}{ll}\text { (O Janis) kseri } & \text { na } \\ \text { John know-3sg } & \text { subj }\end{array}$

'John knows how to swim by himself'

${ }^{5} \mathrm{Na}$ has been analysed as a subjunctive mood marker (cf. Philippaki-Warburton \& Veloudis 1984, PhilippakiWarburton 1990, Rivero 1994) or a subjunctive complementizer (Tsoulas 1993, Aggouraki 1991) or a device to check the EPP (Roussou to appear). Here we side with the first view.
} 

c $\quad$ Ion $_{\mathrm{i}}$ vrea să $\mathrm{EC}_{\mathrm{i} / \mathrm{j}}$ cânte la violoncel Romanian

For both languages, it has been shown that not all subjunctive clauses involve Control. Two main types of subjunctive complements have been recognized: Obligatory Control (OC) ones and non-OC ones (NOC) (or C(ontrolled)-subjunctives and F(ree)-subjunctives in Landau's (2004) terminology), but see Spyropoulos 2007 and Roussou, to appear for certain refinements.

1. OC/C-subjunctives are found as complements of verbs such as ksero 'know how', tolmo 'dare', herome 'be happy', ksehno 'forget', thimame 'remember', matheno 'learn', dokimazo 'try'; aspectual verbs, such as arhizo 'start/begin', sinehizo 'continue. ${ }^{6}$ The ungrammaticality of a DP subject in the embedded clause, different from the matrix subject in (13) - (14) indicates that these verbs are OC:
a. * * Petros kseri na kolimbao pro
Greek
Peter-nom knows subj swim-1sg
b. $\quad *_{0}$ Petros kseri na kolimbai i Maria
Peter-nom knows subj swim-3sg Mary-nom

(14) a. *Ion ştie să cântăm la chitară pro

Romanian

Ion knows subj play-3pl at guitar

b. *Ion ştie să cânte Victor la chitară

Ion knows subj play-3sg Victor at guitar

2. NOC/F-subjunctives are found with e.g. volitional predicates:

a.
o Petros perimeni na erthun
Peter-nom expects subj come-3pl
'Peter expects that they come.'
b. o Petros elpizi na figi i Maria
Peter-nom hopes subj go-3sg Mary-nom
'Peter hopes that Mary goes.'

Greek

(16) a. Petru se aşteaptă să venim.

Romanian

Peter refl expects subj come-1pl

'Peter expects that they come.'

b. $\quad$ Petru speră să plece Maria

Peter hopes subj go-3sg Mary-nom.

'Peter hopes that Mary goes.'

In both languages, OC disallows partial control or split antecedents:

\footnotetext{
6 Note that many predicates that are optional control in Greek correspond to predicates that are obligatory control in English (cf. Joseph 1992, Terzi 1992, Varlokosta 1994, Martin 1996).
} 
a. *I Zoi emathe na kolibane ${ }_{[\mathrm{ECi} /+]}$

Greek

Zoe-nom learnt subj swim-3pl

b. *O Janis ipe oti $\mathrm{i}$ Zoi emathe na kolibane ${ }_{\left[\mathrm{EC} *^{*}+\mathrm{j}\right]}$

John-nom said that Zoe learned-3sg subj swim-3pl
a. * Eu am învățat să înotăm
Romanian
I have learnt subj swim-1stPl
b. *Ion a zis ca tu ai învăţat să înotaţi.
John has said that you-sg have learnt subj swim-2ndPl

\subsection{Raising subjunctives}

Two raising environments have been identified in the literature (see Alexiadou \& Anagnostopoulou 1999; Anagnostopoulou 2003 for Greek; Dobrovie-Sorin 1994, 2000, Alboiu 2007 and references therein for Romanian): (i) complements of aspectual verbs ${ }^{7}$ such as stop, continue, begin and (ii) complements of the verbs seem, happen. The status of the latter environment is controversial in Greek, but not in Romanian. For Greek we will limit the discussion to aspectuals; for Romanian we will also include seem.

We first demonstrate that the constructions in question are biclausal. This can be shown on the basis of event modification and the presence of separate negations (compare the data below to the Adyghe examples (4)):

\section{Greek}

a.

\begin{tabular}{|c|c|c|c|}
\hline Afti tin xronia & arxisa & pirovolo & dio fores \\
\hline $\begin{array}{l}\text { This the year } \\
\text { me to oplo mu ] }\end{array}$ & started-1sg & shoot-1sg & two times \\
\hline with the gun my & & & \\
\hline 'This year I starte & shoot my gi & two times (in a row). & \\
\hline Aftin tin xronia & arxisa & dio fores $\quad[\mathrm{na}$ & pirovolo \\
\hline This the year & started-1sg & two times & shoot \\
\hline $\begin{array}{l}\text { me to oplo mu } \\
\text { with the gun my] }\end{array}$ & & & \\
\hline
\end{tabular}

(20)
a. Den sinexisa [na magirevo]
Neg continued-1sg [subj cook-1sg]
'I didn't continue to cook'
b. Sinexisa [na min magirevo]
Continued-1sg [subj neg cook-1sg]
'I continued not to cook.'
c. Den sinexisa [na min magirevo]
Neg continued-1sg [subj neg cook-1sg]
'I didn't continue not to cook (i.e. I started cooking).'

\footnotetext{
7 Alexiadou \& Anagnostopoulou (1999) showed that Greek aspectual verbs are ambiguous between Control and Raising structures and similar effects hold for Romanian; in all the examples discussed here we show that these verbs qualify as Raising and not as OC ones.
} 


\section{Romanian}

(21) a. Anul acesta am început [să trag de două ori cu pistolul]. year-the this have-1sg started subj shoot-1sg of two times with gun-the 'This year I started to shoot the gun two times (in a row).'

b. Anul acesta am început de două ori [să trag cu pistolul]. year-the this have-1sg started of two times subj shoot-1sg with gun-the 'This year there were two times that I started shooting with.'

(22) a. $\mathrm{Nu}$ am continuat [să gătesc].

Neg have-1sg continued subj cook-1sg

'I didn't continue to cook. (i.e. I stopped cooking.)'

b. Am continuat [să nu gătesc].

have-1sg continued subj Neg cook-1sg

'I continued not to cook.'

c. $\mathrm{Nu}$ am continuat [să nu gătesc].

Neg have-1sg continued subj Neg cook

'I didn't continue not to cook. (i.e. I started cooking.)'

We now proceed to the Raising/LDA properties of these constructions (see Alexiadou \& Anagnostopoulou 1999; Anagnostopoulou 2003 for more raising tests):

1. Weak Crossover (WCO) and Clitic Doubling: an initial argument for Raising comes from the interaction between clitic doubling of the object and obviation of WCO effects. In Greek and Romanian WCO effects arise when the quantificational object is non clitic-doubled $(23 \mathrm{~b} / 24 \mathrm{~b})$. When the quantificational object undergoes clitic doubling, the WCO effects are obviated (23c/24c) (cf. Alexiadou \& Anagnostopoulou 1997):

a. Kathe mitera sinodepse to pedhi tis sto sxolio.

Greek

Every mother accompanied the child hers at school

'Every mother accompanied her child to school.'

b. ?*I mitera tu sinodepse to kathe pedhi sto sxolio

The mother his accompanied the every child at school

?*His mother accompanied every child to school

c. I mitera tu to sinodepse to kathe pedhi sto sxolio.

the mother his cl-acc accompanied the every child at school

'His mother accompanied each child to school.'

(24) a. Fiecare mamă a însoțit copilul ei la şcoală.

Romanian every mother has accompanied child-the her at school

'Every mother accompanied her child to school.'

b. $\quad *$ Mama lui $i_{i}$ a însoțit fiecare copil $1_{i}$ la şcoală.

mother his has accompanied every child at school

c. Mama lui $i_{i} \mathbf{l}$-a însoțit pe fiecare copil $l_{i}$ la şcoală.

mother his him-has accompanied PE every child at school

'His mother accompanied every child to school.'

Alexiadou \& Anagnostopoulou (1999) argue that this effect can be analysed as the result of object raising to the position of the clitic in combination with subject reconstruction to a position lower than the clitic position. Backward binding as in $(23 \mathrm{c}),(24 \mathrm{c})$ follows from the 
assumption that binding is computed on the basis of the derived position of the quantificational object, i.e. the clitic position, and the vP-internal position of the subject which contains the pronominal variable.

The same effect is found with aspectual verbs. WCO effects arise when the quantificational object of the embedded verb $(25 \mathrm{~b} / 26 \mathrm{~b})$ is not doubled and the matrix subject contains a pronominal variable. On the other hand, when the embedded object undergoes clitic doubling, the WCO effects disappear $(25 / 26 \mathrm{c})$.

(25) a. Kathe mitera arxise na sinodevi to pedhi tis sto sxolio. Every mother started subj accompany the child hers at school 'Every mother started to accompany her child to school.'

b. $\quad$ ?*I mitera tu arxise na sinodevi to kathe pedhi sto sxolio The mother his started subj accompany the every child at school '?*His mother started to accompany every child to school'

c. I mitera tu arxise na to sinodevi to kathe pedhi the mother his started subj cl-acc accompany the every child sto sxolio at school 'His mother started to accompany each child to school.'

(26) a. Fiecare mamă a început să insoțească copilul ei la şcoală. every mother has started subj accompany child her at school 'Every mother started to accompany her child to school'.

b. *Mama lui $i_{i}$ a început să însoțească fiecare copil ${ }_{i}$ la şcoală. Mother his started subj accompany every child to school. 'His mother started to accompany every child to school.'

c. Mama lui $\quad$ a început să -1 însoțească pe fiecare copil la şcoală.

Mother his started subj-cl.Acc accompany pe every child to school.

'His mother started to accompany every child to school.'

This argues for Raising, since the matrix subject containing the pronoun may reconstruct to the embedded $\mathrm{vP}$-internal position below the derived position of the doubled quantificational object. Obviation of WCO effects under doubling is impossible with OC verbs:

?*I mitera tu kseri na to sinodevi to kathe pedhi sto sxolio the mother his knows subj cl-acc accompany the every child at school

?? Mama lui ştie să -1 însoțească pe fiecare copil la şcoală.

Mother his knows subj-cl.Acc accompany pe each child at school.

This is expected, because reconstruction of the matrix subject to an embedded position is impossible under control. ${ }^{8}$

\footnotetext{
${ }^{8}$ This contrast between raising and control in Greek is reminiscent of the following contrast in English:

(i) a. $\quad\left[\mathrm{His}_{\mathrm{i}} \text { father }\right]_{\mathrm{j}}$ seems to every boy $\mathrm{H}_{\mathrm{i}}\left[\mathrm{t}_{\mathrm{j}}\right.$ to be a genius $]$

b. $\quad * ?\left[\mathrm{His}_{\mathrm{i}} \text { father }\right]_{\mathrm{j}}$ promised every boy $\mathrm{i}_{\mathrm{i}}\left[\mathrm{PRO}_{\mathrm{j}}\right.$ to be a genius]

In (ia) the matrix subject reconstructs to the trace position where it can be bound by the quantificational object and therefore variable binding is possible. In (ib), however, this is not possible resulting in a WCO violation.
} 
2. Idioms: A further argument, also illustrating the LDA pattern, comes from idioms. Fixed nominatives as part of idiomatic expressions in Greek and Romanian tend to occur in postverbal position.
bikan psili st'aftia.
Greek
cl-1st: sg:gen entered-3pl fleas-nom in the ears
'I became suspicious.'
b. \#Psili mu bikan st'aftia
c. I s-au înecat corăbiile.
Romanian
'He is very sad.'
d. $\quad$ \#Corăbiile i s-au înecat.

Examples like (29a/c) can be embedded under aspectual verbs. The subject in the embedded clause agrees with the embedded and the matrix verb:

Stamatisan/arxisan na mu benun psili st'aftia.

Stopped-3pl/started-3pl subj cl-1st:sg:gen enter-3pl fleas-nom:pl in the ears

'I stopped being/started becoming suspicious.'

Au început să i se înece corăbiile.

have-3pl started subj him-dat refl drown ships

'He started being very sad.'

Idioms are impossible with OC verbs, which have a thematic subject position.

$$
\begin{aligned}
& \text { *Kserun na mu benun psili st'aftia } \\
& \text { Know-3pl subj cl-1st:sg:gen enter-3pl fleas-nom in the ears }
\end{aligned}
$$

*Ştiu să i se înece corăbiile.

Know-3pl subj him-dat refl drown ships

In $(30 / 31)$, the nominative depends on the lower verb for its interpretation and yet it agrees with both verbs obligatorily, as shown by the ungrammaticality of examples lacking matrix verb agreement. ${ }^{9}$

$$
\begin{aligned}
& \text { *Stamatise/arxise na mu benun psili st'aftia } \\
& \text { Stopped-3sg/started-3sg subj cl-1st:sg:gen enter-3pl fleas-nom in the ears }
\end{aligned}
$$

*A început să i se înece corăbiile.

Has-3sg started subj him-dat refl drown ships

\footnotetext{
${ }^{9}$ Other examples of idioms containing plural subjects which show the pattern in (30), (31) are:

(i) Arxisan/*arxise [na mu anavun ta lambakia]

Started-3pl/*started-3sg [subj me-DAT turn on-3pl the lambs]

'I started being furious'

(ii) Arxisan $/ *$ arxise [na mu vgainun kapni apo ti miti]

Started-3pl/*started-3sg [subj me-DAT come out-3pl smoke-pl from the nose]

'I started being furious'
} 
As already discussed, there are in principle two possible analyses for obligatory agreement between the matrix verb and the embedded subject. (i) Raising of the subject to the matrix subject position either covertly (at LF) or overtly with subsequent deletion of the higher copy, as in P\&P's analysis of Adyghe. ${ }^{10}$ (ii) Alternatively, the subject remains in situ and agreement with the matrix verb is a genuine case of LDA as a result of Agree. The raising analysis has been adopted by Alexiadou \& Anagnostopoulou (1999) in a framework lacking Agree. We will see, however, that the latter option is the correct one for Greek and Romanian.

\section{Backward Raising?}

In both Greek and Romanian, nominatives can freely occur in situ in the embedded clause, as in (36), or raise into the matrix clause, as illustrated by the WCO cases in (25) and (26) above. The in situ DP subject obligatorily agrees with both the matrix and the lower verb in person and number, just as in the idiom cases discussed in the preceding section:
a.
stamatisan/*stamatise na malonun
i daskali tus mathites
Greek stopped-3pl/stopped-3sg subj scold-3pl the teachers the students 'The teachers stopped scolding the students.'
b. Au încetat $/ * A$ încetat să -i certe profesorii pe elevi.
Romanian stopped-3pl/stopped-3sg subj-clitic-3pl.Ac scold-3pl the teachers the students 'The teachers stopped scolding the students.'

In (36) the agreeing subject resides in the embedded clause and has not undergone scrambling to the matrix clause (an option systematically instantiated in Russian, as extensively argued for by P\&P 2008). The subject is truly embedded (i.e. not situated in the higher clause) as it precedes objects (note the VSO order in (36)) and VP-modifiers of the lower verb. In (37) the event adverbial modifies either the matrix or the embedded verb.
Stopped-3sg
to pukamiso
a. Stamatise na
ksevgazi
o Janis
Greek
rinse-3sg
the Janis-nom
the shirt-acc
tesseris fores
four times
b. A încetat [să clăteasca Ion camaşa de patru ori.]
Romanian
has-3sg stopped subj rinse-3sg John shirt-the of four times
'John stopped rinsing the shirt four times (in a row).'
'Low interpretation: John stopped rinsing the shirt four times (in a row).'
'High interpretation: It was four times the case that John stopped rinsing the shirt.'

This difference in interpretation depends on the adjunction site of the adverb. In the high reading where it modifies the matrix verb it (right-) adjoins to the matrix $\mathrm{vP} / \mathrm{TP}$ :

\footnotetext{
${ }^{10}$ Alexiadou \& Anagnostopoulou (1999) also consider the possibility of overt or covert feature movement, a possibility we disregard here.
} 


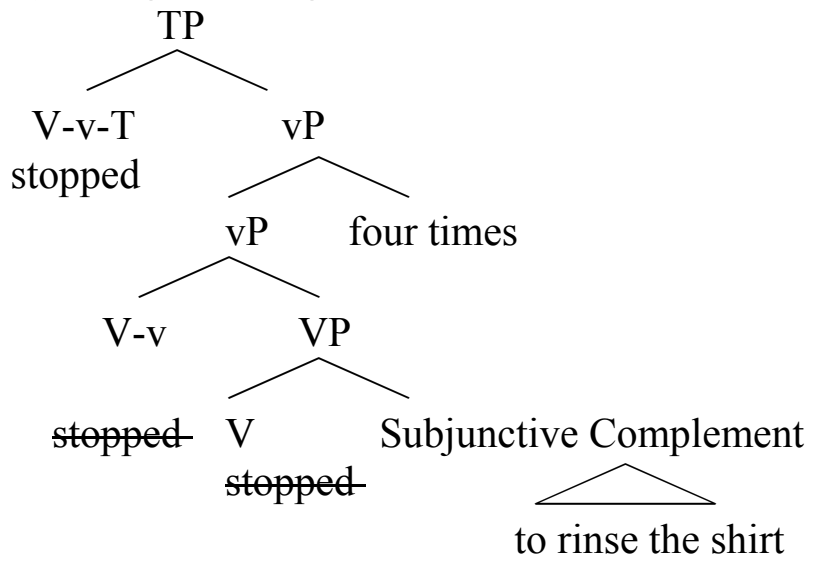

When it modifies the embedded verb, it adjoins to the embedded vP/TP:

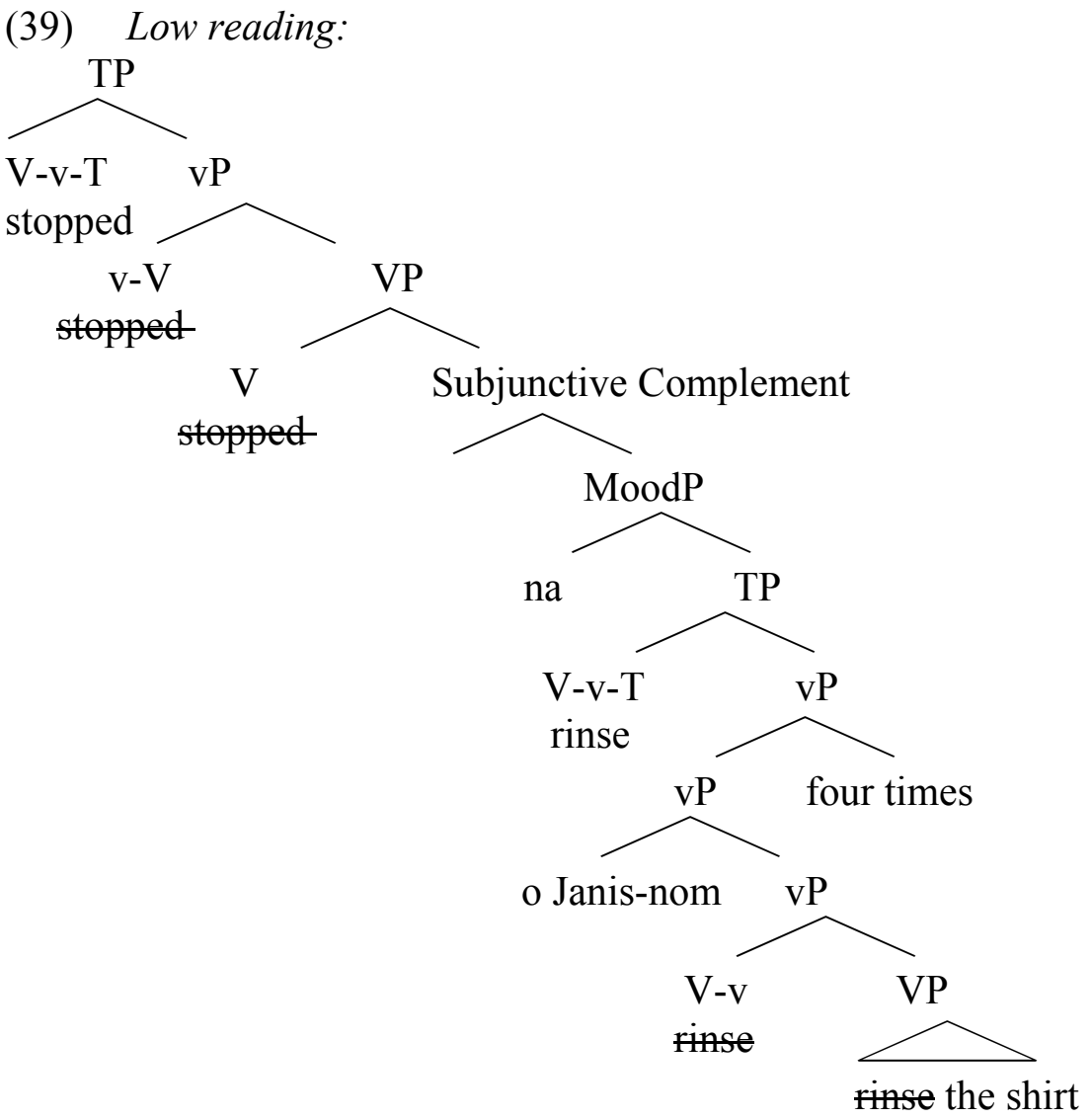

As illustrated in (39), the subject necessarily resides in the embedded clause when the adverb modifies the predicate of the embedded clause. ${ }^{11}$ Although the fact that the subject follows the subjunctive marker would be enough to show that the subject is in the embedded clause, one could argue that the embedded subject has been left-ward moved to the higher clause (I. Landau pc). But if the subject was part of the higher clause, the adverbial would be higher as

\footnotetext{
${ }^{11}$ As is standardly assumed, the verb raises to $\mathrm{T}$ in Greek and Romanian (see Alexiadou 1997; Alexiadou \& Anagnostopoulou 1998, 2001, Cornilescu 2000, Dobrovie-Sorin 1994, among many others). Alexiadou \& Anagnostopoulou $(1998,2001)$ extensively argue that postverbal subjects in these languages are vP internal. The trees in (38) and (39) follow these analyses for ease of exposition. The main point of the argument presented in the main text does not crucially depend on this particular analysis of VSO orders.
} 
well, adjoined to the higher clause, resulting in the high reading obligatorily. Note that the adverb only has matrix scope in (40) where it clearly modifies the matrix verb:
tesseris fores [na ksevgazi o Janis
to pukamiso]
Stopped-3sg four times [subj rinse the Janis-nom the shirt-acc] 'It was four times the case that Janis stopped rinsing the shirt.'
b. A încetat de patru ori [să clăteasca Ion cămaşa]. has-3sg stopped of four times subj rinse John shirt-the 'It was four times the case that John stopped rinsing the shirt.'

Having presented evidence that the subject is truly embedded, let us now turn to the raising vs. LDA question. P\&P (2008) provide evidence that in Greek there is no copy in the matrix clause in support of the latter option; we show here that similar facts hold in Romanian (cf. Rivero \& Geber 2008). P\&P's main arguments come from scope: while the matrix subject DP takes wide scope with respect to the raising verb $(41 \mathrm{a} / 42 \mathrm{a})$, the unraised one only has narrow scope $(41 \mathrm{~b} / 42 \mathrm{~b})$ :

(41) a. mono i Maria stamatise na perni kakus vathmus only Mary stopped subj get-3sg bad grades 'It is only Maria who stopped getting bad grades.' ONLY $>$ STOP

b. stamatise na perni mono i Maria kakus vathmus stopped subj get-3sg only Maria bad grades 'It stopped being the case that only Maria got bad grades.' STOP $>$ ONLY

(42) a. Numai Maria a încetat să ia note slabe. ${ }^{12}$ Only Mary stopped subj get grades weak. 'It is only Maria who stopped getting bad grades.' ONLY $>$ STOP

b. A încetat să ia numai Maria note slabe. Stopped subj get only Mary grades weak 'It stopped being the case that only Mary got bad grades.' STOP $>$ ONLY

In this respect, Greek and Romanian differ from Adyghe where downstairs subjects may take wide scope, as discussed in P\&P $(2007,2008)$.

A further environment where Greek and Romanian differ from Adyghe concerns the scope interaction between the subject DP and the matrix negation. The matrix quantified subject allows wide scope with respect to clause-mate negation, while the unraised one takes only narrow scope with respect to matrix negation. In Adyghe, on the other hand, the downstairs quantified DP has wide scope over the matrix negation, regardless of its linear position.

a. oli $\mathrm{i}$ fitites den arhisan na diavazun afto to vivlio all the students neg began. $3 \mathrm{pl}$ subj read.3pl this the book 'All the students did not begin to read this book.'

b. den arhisan na diavazun oli i fitites afto to vivlio neg began.3pl subj read.3pl all the students this the book 'Not all the students began to read this book.'

ALL $>$ NEG

NEG $>$ ALL

\footnotetext{
${ }^{12}$ Note that the same judgements hold in Romanian for the infinitival Raising constructions. We would like to point out here that with 'seem' Romanian only has the SEEM $>$ ONLY reading, irrespectively of the surface position of the subject, i.e. before the raising verb or in the embedded clause.
} 
(44) a. Toți studenții nu au început să citeasca această carte.

All students-the not have began.3pl subj read this book.

'All students did not begin to read this book.'

ALL $>$ NEG

b. $\quad$ Nu au început să citeasca toți studenții această carte.

Neg have.3pl begin subj read.3pl all students-the this book

'Not all the students began to read this book.'

$\mathrm{NEG}>\mathrm{ALL}$

We would like to add a further argument for the LDA analysis, relating to the licensing of predicative modifiers. In Greek and Romanian, nominal secondary predicates and predicative modifiers like "alone" agree in gender and number with the c-commanding DP they modify:

a. O Janis efige panikovlitos $/ *_{\mathrm{i}}$

Greek

Janis-nom left panicking-ms/fem

lit. 'Janis left in panic.'

b. O Janis irthe monos tu/*moni tis

John-nom came alone-ms/alone-fem

'Janis came alone.'

(47)
a. $\quad$ Ion a plecat panicat/*ă
Ion left panicking-ms/fem
'Ion left in panic.'
b. $\quad$ Ion a venit singur/ *ă.
Ion came alone-ms/alone-fem
'Ion came alone.'

If this were a BR construction, we would expect such modifiers to be licensed in the matrix clause, while the DP they modify resides in the embedded clause. This is impossible, however, providing evidence against BR and in favor of LDA.

It has been mentioned in footnote 7 that aspectual verbs in Greek and Romanian are ambiguous between a raising and a control construal. There is one environment where raising aspectuals behave differently than their control counterparts with respect to their Case/agreement properties (see Alboiu 2007, and Alexiadou \& al. to appear for a detailed discussion). When a quirky subject construction is embedded under aspectuals, OC aspectuals agree in person and number with the embedded quirky dative subject, as shown in (48a). On the other hand, raising aspectuals agree in person and number with the embedded nominative theme argument regardless of the surface position of the quirky subject, i.e. whether it remains in the embedded clause (as in $48 \mathrm{~b}$ ) or it raises to the matrix clause (as in 48c):

$\begin{array}{lllllll}\text { a. } & \text { ?Arxise } & \text { na } & \text { min tis ksefevgun } & \text { tis } & \text { Marias } \\ \text { Started-3sg subj not cl-gen escape-3pl } & \text { the } & \text { Mary-gen } \\ \text { polla lathi } & & & & & \\ \text { many mistakes-pl } & & & & \\ & \text { 'Mary started not to miss so many mistakes' } & & \\ \text { b. } & \text { Arxisan na } \quad \text { min tis ksefevgun } & \text { tis } & \text { Marias } \\ & \text { Started-3pl subj not cl-gen escape-3pl } & \text { the } & \text { Mary-gen } \\ \text { polla lathi } & & & & \\ \text { many mistakes-pl } & & & & \end{array}$




$\begin{array}{llllll}\text { c. Tis Marias } & \text { arxisan } & \text { na } & \text { min } & \text { tis } & \text { ksefevgun } \\ \text { The Mary-gen } & \text { started-3pl } \\ \text { polla lathi } & \text { subj } & \text { not } & \text { cl-gen escape-3pl } \\ \text { many mistakes-pl } & & & & \end{array}$

That (48a) contains a thematic subject position while (48b) doesn't is evidenced by the fact that agent-oriented adverbs are licensed in (48a) but not in $(48 b) /(48 c)$, as shown in (49):

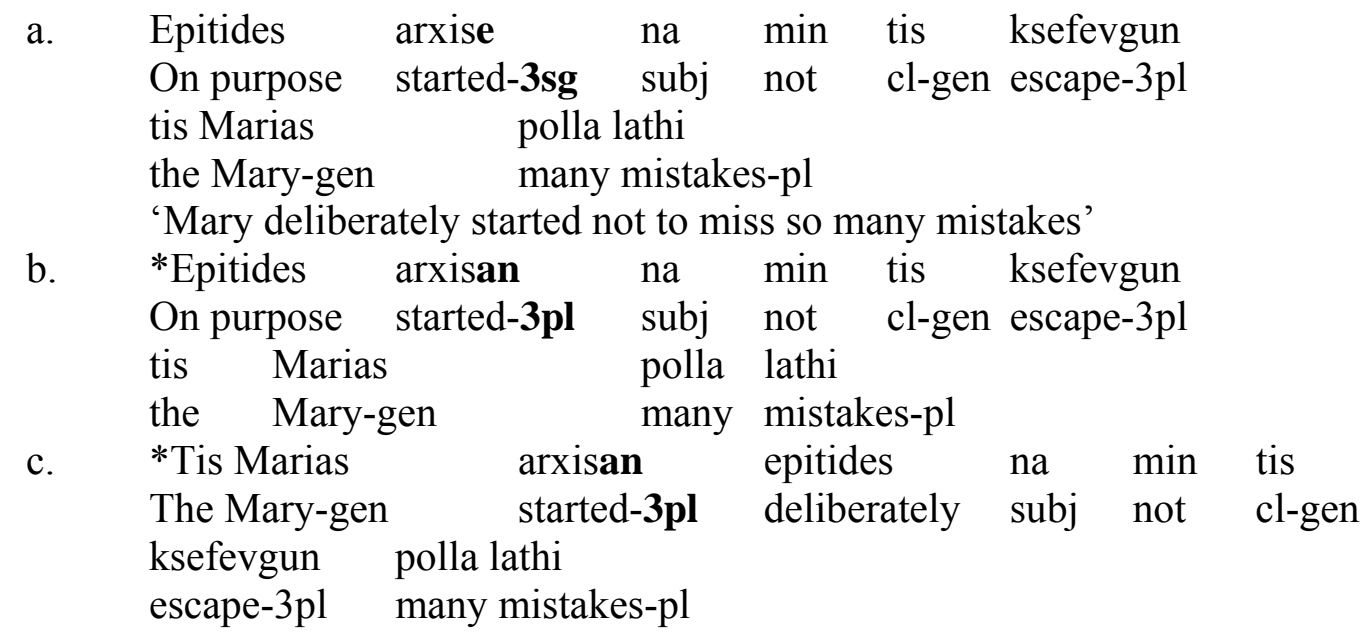

The predicative modification diagnostic can now be applied to the unambiguously raising construction exemplified in $(48 \mathrm{~b}, \mathrm{c})$. Adding a predicative modifier to the nominative argument is grammatical only when the modifier occurs in the embedded clause, as in (50a), and not when the modifier occurs in the matrix clause, as in $(50 \mathrm{~b})^{13}$ :
a. arhisan apo fetos na mu aresun ta kreata oma started-3pl from this year subj me-gen like the meat-pl raw
b. $\quad$ *arhisan oma apo fetos na mu aresun ta kreata started-3pl raw from this year subj me-gen like the meat--pl

The ungrammaticality of (50b) entails that there is no silent copy of the nominative in the matrix clause in Greek, unlike Adyghe. Similar observations hold for Romanian.

We thus conclude - in agreement with P\&P - that Greek and Romanian (cf. Alboiu 2007 and Rivero \& Geber 2008) have fake BR, as there is no higher copy in the matrix clause. The apparent backward raising phenomenon attested in these languages is actually an instance of LDA between the matrix $\mathrm{T}$ and the embedded in situ nominative argument.

\section{Accounting for the properties of the situ patterns}

In both Greek and Romanian, the absence of a copy in the raising verb's clause accounts for the low characteristics of the subject. Agreement between the matrix verb and the embedded subject must be determined non-locally, across a clause boundary, as in (54), from Polinsky \& Potsdam (2008):

\footnotetext{
${ }^{13}$ In order to control for the adjective being interpreted as focussed in the left periphery of the embedded clause, we include an adverbial clearly modifying the matrix verb in our examples.
} 


\begin{tabular}{cllll}
\multicolumn{2}{c}{ Agree } & & & LDA \\
\cline { 2 - 3 } & $\begin{array}{l}\text { arhisan } \\
\text { started-3pl }\end{array}$ & {$[\mathrm{CP} / \mathrm{TP}$} & na & trehun \\
subj & run-3pl & $\begin{array}{l}\text { [ta pedia]]] } \\
\text { the children }\end{array}$
\end{tabular}

The children started to run

But how is this possible? We assume, following Chomsky (2001) and Baker (2008: 65) that the central principles governing Agree are as in (52):

(52) Agree occurs between F and XP, XP a maximal projection, only if:

a. F c-commands XP

b. There is no YP such that YP comes between F and XP and YP has phi-features

c. $\quad \mathrm{F}$ and $\mathrm{XP}$ are in the same phase (locality condition)

d. XP is made active by having an unchecked case feature (activation condition)

e. $\quad \alpha$ and $\beta$ become valued for the matched features

In the system of Chomsky $(2000,2001)$, the conditions in (52) can hold if the lower clause is not a phase, i.e. if it lacks a CP layer. Otherwise the Phase Impenetrability Condition would be violated and the embedded subject would be inaccessible for the operation Agree with matrix T. In addition, the subject must be active: it must have an unchecked Case feature. This means that the embedded T lacks Case.

Is there evidence that the locality and the activation condition are met? The answer appears to be positive. Straightforward evidence for the absence of C comes from Romanian where the subjunctive complementizer $c a$ is always absent in LDA constructions (and see Alboiu 2007 for further arguments that the lower clause is not a phase).

$$
\left[\begin{array}{llll}
\text { [TP1 } & \mathrm{T}^{\circ} \quad \text { [TP2anaphoric na/ să NOM }
\end{array}\right.
$$

A început $\quad\left({ }^{*}\right.$ ca) să cânte Maria la pian. ${ }^{14}$

has-3sg started that subj sing Maria at piano

Since the two languages behave identically in every other respect, we assume that a CP layer is also lacking from Greek LDA constructions.

Proceeding to Case and the activation condition, we assume (following Iatridou 1988/1993, Varlokosta 1994, Alexiadou \& Anagnostopoulou 1999, Chomsky 2001, Landau 2004 and others) that Case is a property of complete, i.e. non-deficient Tense. In both Greek and Romanian, LDA subjunctives are characterized by the absence of morphological and semantic Tense, i.e. absence of independent temporal reference in the embedded clause. As (56b) and (57b) show, it is not possible to modify the embedded verb by a temporal adverb with independent reference: ${ }^{15}$

a. $\quad *$ O Janis arhizi na kolibise.

Greek

John begins subj swam-3sg

\footnotetext{
${ }^{14}$ As already pointed out in section 4.1 , OC is also ungrammatical in the presence of the subjunctive complementizer $c a$. This could be taken to point to the conclusion that OC and LDA are identical with respect to locality, which would be expected in an A-movement analysis of OC. This issue requires further investigation, though, since the claim that Control complements lack a CP layer would be highly controversial. In addition, there is a clear difference between OC complements and raising complements with respect to Case, revealed in contexts like (48) and (49) above to be discussed below.

${ }^{15}$ The relationship between Case and Semantic Tense across languages is systematic in Raising constructions. For English, Martin (1996) extensively argues that Raising is contingent on the absence of semantic Tense.
} 
b. *O Janis arhizi na kolibai avrio.

John begins subj swim-3sg tomorrow

a. *Ion începe să a înotat.

Romanian

John begins subj swam-3sg

b. *Ion a început să înoate mâine.

John began subj swim tomorrow

This is in contrast with NOC/F-subjunctives: ${ }^{16}$

o Janis theli na figi avrio

Greek

John-nom wants subj leave-3sg tomorrow

'John wants to leave tomorrow.'

b. o Janis theli na figi i Maria

John-nom wants subj leave-3sg Mary-nom

'John wants Mary to leave.'

Ion a vrut să plece Maria mâine.

Romanian

John-nom wanted subj leave-3sg Maria tomorrow

'John wants Mary to leave tomorrow.'

Lacking Tense, transparent subjunctives also lack Case explaining why the nominative argument obligatorily agrees with the matrix $\mathrm{T}$ in raising subjunctives.

Note in this context that $\mathrm{OC}$ subjunctives differ from raising subjunctives with respect to Case transparency. As has been shown in the previous section, embedded quirky subject constructions provide evidence for the existence of two independent Case/agreement chains with OC aspectuals, unlike raising aspectuals. With OC aspectuals, matrix $\mathrm{T}$ agrees in person and number with the embedded quirky subject (more accurately, it agrees with a silent matrix nominative copy entering control with the embedded quirky subject; see Alexiadou et al. to appear for details), while the embedded $\mathrm{T}$ agrees in person and number with the embedded nominative argument (48a)/ (49a). By contrast, matrix $\mathrm{T}$ obligatorily agrees with the embedded nominative argument in the case of raising aspectuals embedding quirky subjects, as was shown in $(48 \mathrm{~b}, \mathrm{c})$ and $(49 \mathrm{~b}, \mathrm{c})$.

A straightforward account for the fact that subjunctives allowing LDA lack both a CP layer and semantic Tense can be given in Chomsky's (2007) system where Tense features are a property of $\mathrm{C}$ inherited by $\mathrm{T}$. Since $\mathrm{C}$ is missing, Tense and Case are also missing. A consequence of this analysis is that phi-features are not (necessarily) a property of $\mathrm{C}$ since

\footnotetext{
${ }^{16}$ Note here that in Romanian the raising verbs 'seem' and 'happen' behave slightly different (at least for the two native speakers involved in this paper), their complement patterning like F-subjunctives. Specifically, the subjunctive clause has semantic tense, as shown in (i):

(i) (Maria) s -a nimerit (Maria) să plece (Maria) mîine.

Mary refl-has happened (Mary) subj leave Mary tomorrow

'It so happened that Mary would leave tomorrow.' - it happened at that time that Mary would leave later and w.r.t. the time when we speak (now) Mary's leaving will take place tomorrow.

This, in connection with the fact that with these two verbs the DP seems to be in the embedded clause, irrespectively of its surface position (scope interaction mentioned in section 4.2; footnote 11), suggests that complements of 'seem' and 'happen' in Romanian can license nominative and hence the DP is not active for valuation through the matrix verb. If it appears preceding the matrix verb, it is interpreted as a focus or topic (Alboiu 2007). The agreement on the matrix verb is an instance of phi-feature chain formation. See also Rivero \& Geber (2008).
} 
they are present in Greek and Romanian embedded subjunctives allowing LDA. Moreover, the presence of complete phi-feature agreement on the embedded $\mathrm{T}$ shows that phi-feature valuation of the probe does not always result in Case checking of the goal (see Alexiadou \& Anagnostopoulou 1999; cf. Bhatt 2005). Obviously this analysis is incompatible with Chomsky's (2001) claim that $\mathrm{T}$ has phi-features only as a result of Transfer from $\mathrm{C}$ (and see Richards (2007) for further arguments in favor of this view). Can we reconcile this proposal with the situation we find in Greek and Romanian? It seems to us that this is possible either if we follow Alexiadou \& Anagnostopoulou (1999) who treat agreement in Greek and Romanian as being EPP-related or, alternatively, if we assume that this agreement is a surface morphological agreement of the concord type.

More specifically, in A \& A (1999) the Agreement between the embedded verb and the subject DP is analysed as being EPP-driven and not Case driven; as a result, Agreement on the embedded verb is fully specified. There are at least two different ways of further implementing this. One possibility is that agreement may in principle morphologically spell out EPP relations or Case relations, and that languages differ with respect to this. On this view, there are two features associated with T: an EPP feature and a Case feature. Both are formal features of the same type, i.e. [-interpretable] nominal features on functional heads (this is the view adopted in A\&A 1999).

$$
[\text { TP2 } \mathrm{T}<\mathrm{EPP}, \text { Case }>[\mathrm{TP} 1 \mathrm{~T}<\mathrm{EPP}>[\mathrm{vP} \text { DP }]]]
$$

Cross-linguistically then, there are at least two types of Agreement-Case, Agreement-EPP relations (see also Baker 2008: 209 ff. for a similar proposal): (i) Agreement is a reflex of Case-checking. (ii) Agreement is the reflex of EPP checking. The latter pattern is found in Greek and Romanian. On this view, the DP establishes an EPP chain with the embedded T, and both a Case and EPP chain with the higher T. Since the lower T lacks semantic Tense, it also lacks Case as argued above. An alternative possibility is that agreement in Greek is the result of phi-feature movement satisfying EPP (see Alexiadou \& Anagnostopoulou 1998, 2001), i.e. the type of agreement we find in Greek and Romanian is of the clitic doubling type rather than the result of phi-feature valuation via Agree (see Anagnostopoulou 2003 and Preminger 2008 on the distinction between the two types of agreement).

An altogether different approach to pursue would be that the agreement on the embedded verb is somehow 'parasitic' and the only real Agree relationship established is the one between the matrix $\mathrm{T}$ and the embedded DP. This would entail that the phi-features observed on the embedded verb are present due to a well-formedness requirement on all Greek and Romanian verbs, as in (61):

*T-V, when $\mathrm{T}-\mathrm{V}$ bears no phi-features

(61) suggests that in languages which lack infinitives, verbs cannot appear un-inflected, under the assumption that there is no default agreement form to use. Since the embedded T-V complex must bear phi-features, we could imagine that an Agr node is inserted at PF on the lower T-V complex, which copies the features of the embedded subject on it. On this view, agreement on the lower verb is more like agreement within the DP, i.e. it is a case of concord that involves copying of features, as is discussed in Embick (2000) within the framework of Distributed Morphology.

The final question we would like to address in the present context concerns the properties Greek and Romanian have in common which potentially explain the observed LDA 
pattern, i.e. the fact that the subject does not raise to matrix $\mathrm{T}^{17}$ Comparing Greek to Romanian, we observe that they are both alike in that:

1. they have subjunctives in Raising (and no infinitives)

2. they are pro-drop languages

3. they have VSO orders with VP-internal subjects (Alexiadou \& Anagnostopoulou 2001)

4. they have clitic doubling

5. they have been argued to have EPP checking via V-movement (Alexiadou \& Anagnostopoulou 1998)

The fact that both languages have subjunctives cannot be the reason for the presence of LDA, as: (i) Romanian does have infinitival complements of raising verbs and they behave similarly to subjunctives with respect to LDA; ${ }^{18}$ (ii) other languages, e.g. Bulgarian, lack infinitives but also lack fake BR (Adrian Krastev pc); (iii) Spanish has infinitives, but exhibits fake BR. Importantly, Spanish shares with Greek and Romanian all other properties.

That Spanish has LDA is shown by applying the LDA tests to the infinitival constructions of the language. First, like in Greek and Romanian, unraised DPs can be argued to reside truly in the embedded clause. As was the case in Greek and Romanian, the subject resides in the embedded clause and has not undergone (rightward) scrambling to the matrix clause. The subject is truly embedded as it precedes objects (again note the VSO order in (62)) and VP-modifiers of the lower verb. In (62a) the event adverbial modifies either the matrix or the embedded verb. In (62b) it clearly modifies the matrix verb only:

a. Acabó de enjuagar Juan la camiseta cuatro veces.

Stopped-3sg prep. to rinse-Inf. John the shirt for times

Low interpretation: 'John stopped rinsing the shirt four times.'

High interpretation: 'It was four times the case that John stopped rinsing the shirt.'

b. Acabó cuatro veces de enjuagar Juan la camiseta.

Stopped-3sg four timed prep. to rinse-inf. John the shirt

High interpretation: 'it was four times the case that John stopped rinsing the shirt.'

Second, in situ subjects take narrow scope with respect to the raising verb and matrix negation:

a. Solamente María acabó de tomar notas malas only Mary stopped DE get grades bad

'It is only Maria who stopped getting bad grades.'

ONLY $>$ STOP

b. Acabó de tomar solamente María notas malas. stopped subj get-3sg only Maria bad grades 'It stopped being the case that only Maria got bad grades.' STOP > ONLY

\footnotetext{
${ }^{17}$ A question arises here: do these languages disallow raising altogether or is raising optional? If the former, then examples with the subject in the matrix clause do not involve A-movement to matrix $\mathrm{T}$ but some other operation. It would be natural to pursue this option extending to these cases Alexiadou \& Anagnostopoulou' s (1998) analysis of SVO orders in Greek and Romanian in terms of Clitic Left Dislocation. See Alboiu (2007) for an explicit such proposal. This requires further research on the A/A' status of the raised subject. See also footnote 16.

${ }^{18}$ Note also here that the languages discussed by P\&P have infinitives in BR.
} 
(64) a. Todos los estudiantes no empezaron a leer este libro.

All the students not began. $3 \mathrm{pl}$ to read this book

'All students did not begin to read this book.'

ALL $>$ NEG

b. No empezaron a leer todos los estudiantes este libro.

Neg begin to read all the students this book.

'Not all the students began to read this book.'

$\mathrm{NEG}>\mathrm{ALL}$

Third, licensing of modifiers in the matrix clause is ruled out, as in Greek and Romanian:

a. Parece venir solamente María mal preparada a la escuela.

Seem come only Mary bad prepared-fem at the school.

b. ??Parece mal preparada venir solamente María a la escuela.

Seem bad prepared-fem come only Mary at the school

(66) a. Ha empezado al final del año a venir Juan solo a la escuela.

Have.3sg begun towards the end of the year to come John alone to the school.

'John began coming alone to school towards the end of the year.'

b. *Ha empezado solo al final del año a venir Juan a la escuela.

Have.3sg begun alone towards the end of the year to come John to the school.

It can thus be concluded that the existence of productive LDA patterns derives from properties 2-5, i.e. pro-drop, VSO orders with vP-internal subjects, clitic doubling and EPP checking via V-raising. Alexiadou \& Anagnostopoulou $(1998,2001)$ have proposed that these properties are a reflex of a single one: the extensive availability of clitic/agreement-associate relationships in a language which permit DPs to remain in situ. ${ }^{19}$

\footnotetext{
${ }^{19}$ As already mentioned, in those papers, it was argued that Agreement (with clitic properties) satisfies the (EPP, Case) requirements of the higher clause so that the lower copy can be spelled out in a lower domain. This was seen as a case of feature movement. If we stick to this view, then the contrast between Greek/Romanian and Adyghe is not lack of movement (LDA) vs. movement, but rather $\mathrm{X}^{\circ}$ (feature) vs. XP movement in terms of Copy and Delete.
} 


\section{References}

Agouraki, Y. 1991 A Modern Greek Complementizer and its significance for Universal Grammar. UCL Working Papers in Linguistics 3:1-24.

Alboiu, G. 2007. Moving forward with Romanian Backward Control and Raising. In W. Davies \& S. Dubinsky (eds.) New horizons in the analysis of control and raising. Springer.

Alexiadou, A. 1997. Adverb placement: a case study in antisymmetric syntax. John Benjamins.

Alexiadou, A. \& E. Anagnostopoulou. 1998. Parametrizing Agr: Word Order, V-movement and EPP-checking. Natural Language and Linguistic Theory 16: 491-539.

Alexiadou, A. \& E. Anagnostopoulou. 1999. Raising without infinitives and the nature of Agreement. Proceedings of WCCFL 18.

Alexiadou, A. \& E. Anagnostopoulou. 2001. The subject in situ generalization and the role of Case in driving computations. Linguistic Inquiry 32: 193-231.

Alexiadou, A., E. Anagnostopoulou, G. Iordachioaia \& M. Marchis (to appear). A stronger argument for Backward Control. Proceedings of NELS 39.

Anagnostopoulou, E. 2003. The syntax of ditransitives: evidence from clitics. Mouton de Gruyer.

Baker, M. 2008. The syntax of Agrement and Concord. Cambridge: Cambridge University Press.

Bhatt, R. 2005. Long distance agreement in Hindi-Urdu. Natural Language and Linguistic Theory 23: 757-807.

Chomsky, N. 1973. Conditions on transformations. In S. R. Anderson \& P. Kiparsky (eds.) A festschrift for Morris Halle. New: York: Holton, Rinehart and Winston.

Chomsky, N. 2000. Minimalist inquiries. In R. Martin \& al. (eds.) Step by step: essays on minimalism in honor of Howard Lasnik, 89-115. Cambridge, Ma: MIT Press.

Chomsky, N. 2001. Beyond explanatory adequacy. In A. Belleti (ed.) Structures and beyond. Oxford: Oxford University Press.

Chomsky, N. 2007. Approaching UG from below. In Interfaces + recursion = language? Chomsky's minimalism and the view from semantics, ed. U. Sauerland \& H.M. Gärnter. Mouton de Gruyter.

Cornilescu. A. 2000. The double subject construction in Romanian. In V. Motapanyane ed. Comparative Studies in Romanian Syntax, 83-134. Dordrecht: Elsevier.

Dobrovie-Sorin. C. 1994. The syntax of Romanian. Berlin: Mouton de Gruyter.

Dobrovie-Sorin. C. 2000. Head-to-Head Merge in Balkan Subjunctives and Locality, in A. Ralli \& M-L. Rivero, eds. Comparative Syntax of Balkan Languages, Oxford University Press.

Embick, D. 2000. Syntax and Categories: Verbs and Participles in the Latin Perfect. Linguistic Inquiry 31 185-230.

Grosu, A. \& J. Horvath. 1987. On non-finiteness in extraction constructions. Natural Language and Linguistic Theory 5: 181-196.

Hornstein, N. 1999. Movement and Control. Linguistic Inquiry 30: 69-96.

Iatridou, S. 1993. On Nominative Case Assignment and a few related things. MIT Working Papers in Linguistics 19:175-198.

Kapetangianni, K. \& T.D: Seely. 2007. Control in Modern Greek: it's another good move. In W. Davies \& S. Dubinsky (eds.) New horizons in the analysis of control and raising. Springer.

Landau, I. 2004. The scale of finiteness and the calculus of Control. Natural Language and Linguistic Theory 22: 811-877. 
Landau, I. 2007. Movement resistant aspects of Control. In W. Davies \& S. Dubinsky (eds.) New horizons in the analysis of control and raising. Springer.

Martin, R.A. 1996. A Minimalist Theory of PRO and Control. Doctoral dissertation, University of Connecticut.

Motapanyane, V. 1995. Theoretical implications of complementation in Romanian. Padova: Unipress.

Philippaki-Warburton, I. \& J. Veloudis. 1984. The Subjunctive in Complement Clauses, Studies in Greek Linguistics 5.

Philippaki, I. \& G. Catsimali. 1999. On Control in Greek. Studies in Greek Syntax, eds. A. Alexiadou, G. Horrocks, and M. Stavrou. Dordrecht: Kluwer.

Polinsky, M. \& E. Potsdam. 2007. Expanding the scope of control and raising. In W. Davies $\&$ S. Dubinsky (eds.) New horizons in the analysis of control and raising. Springer.

Polinksy, M. \& E. Potsdam. 2008. Real and apparent long-distance agreement in Subject-to subject raising constructions. Paper presented at the workshop on Local-modelling of nonlocal dependencies, DGfS XXX, Bamberg.

Preminger, O. 2008. Breaking Agreements: Distinguishing Agreement and Clitic-Doubling by Their Failures. Ms. MIT.

Richards, M. 2007. Deriving the edge: whats' in a phase. Ms., Universität Leipzig.

Rivero, M. 1994. The Structure of the Clause and V-movement in the Languages of the Balkans. Natural Language and Linguistic Theory 12:63-120.

Rivero, M.L. \& D. Geber. 2008. Experiencer islands and raising in Romanian. Ms. University of Ottawa.

Roussou, A. to appear. In the mood for Control. Lingua.

Spyropoulos, V. 2007. Finiteness and Control in Greek. In W. Davies \& S. Dubinsky (eds.) New horizons in the analysis of control and raising. Springer.

Terzi, A. 1992. PRO in Finite Clauses: a Study of the Inflectional Heads of the Balkan Languages. Doctoral dissertation, CUNY.

Tsoulas, G. 1993. Remarks on the structure and the interpretation of na-clauses. Studies in Greek Linguistics 14.

Varlokosta, S. 1994. Issues on Modern Greek Sentential Complementation. Doctoral dissertation, University of Maryland. 